Editorial

\title{
Hormonal Contraceptives and Risk of Breast Cancer: How to Explain it without Controversy
}

\section{Contraceptivos hormonais e risco de câncer de mama: como explicar sem polêmica}

Rogério Bonassi Machado ${ }^{1,2}$

\author{
${ }^{1}$ Faculdade de Medicina de Jundiaí, Judiaí, SP, Brazil \\ 2 President of the National Committee Specialized in Birth Control, \\ Federação das Associações de Ginecologia e Obstetrícia, São Paulo, \\ SP, Brazil
}

Rev Bras Ginecol Obstet 2018;40:57-58.

Globally, hormonal contraceptives (HCs) are used by approximately $13 \%$ of the female population between 15 and 49 years old, which, in absolute numbers, represents 140 million women. ${ }^{1}$ In Brazil, where the rates of tubal ligation are $29 \%$, HCs are used by approximately $30 \%$ of women of reproductive age. ${ }^{2}$

The roles of the hormones contained in HCs have long been discussed. Estrogens appear to function as promoters of mammary tumors; however, their role as initiators of carcinogenesis is controversial, as is the complex role of progestins. ${ }^{3}$ Studies that address the association between breast cancer and HCs are usually restricted to combined oral contraceptives (COCs). Even though older studies have shown greater risk of breast cancer among women on the pill, ${ }^{4}$ since 2002, the evidence has not demonstrated this association. ${ }^{5-8}$

In December 2017, the New England Journal of Medicine published a study by Mørch et $\mathrm{al}^{9}$ in which they presented the results of a 10.9-year prospective cohort study involving 1.8 million women in Denmark who were on HCs. The study investigated the association between HCs and the risk of breast cancer for this population, when compared with women who did not use HCs.

During the follow-up period, 11,517 cases of breast cancer occurred. The relative risk of breast cancer among recent users of any type of $\mathrm{HC}$ was of 1.20 (95\% confidence interval [95\%CI]: 1.14-1.26). Among the different combination (estrogen-progestin) contraceptives, the relative risk varied between 1.0 and 1.6. Higher risk of breast cancer was also observed among users of the levonorgestrel intrauterine system (relative risk [RR]: 1.21; 95\%CI: 1.11-1.33). Furthermore, the risk increased with longer durations of HC use.

In general, critical analyses of high-impact articles tend to focus on possible biases that, for the most part, are already addressed by the authors themselves. This includes the difficulty in controlling confounding factors, such as age of menar- che, breastfeeding, alcohol consumption, physical activity, and body mass index. Moreover, the Danish study also showed that the risk of breast cancer usually disappeared rapidly after the interruption in the use of these contraceptives.

Indeed, there are no perfect studies. However, the quality of the study published by the Danish group is undeniable. Thus, the key question with regard to this publication would be better framed as the impact that its dissemination might have on physicians and, ultimately, patients. Essentially, the study assessed the risk of women presenting the disease they fear the most. The term "relative risk" was used to address the topic, as is common in the medical literature. In the introduction, the authors reported that the risk of cancer among HC users could increase by $20 \%$ to $30 \%$. This statement was absolutely correct, based on studies that have shown relative risks ranging between 1.2 and 1.3. However, when the subject is addressed using risk percentages, which are typically expressed in terms of relative risk, the scale of such risks may be overrated, especially among the non-medical audience. When presented in terms of incidence or prevalence, risks of disease are easier to understand.

Referring to absolute risk is more precise. Thus, according to the study by Mørch et al, ${ }^{9}$ the absolute risk of breast cancer associated with any HC was 13 per 100,000 women-years, which corresponds to 1 extra case of breast cancer for every 7,690 HC users in 1 year. Clinical judgements after having analyzed these data led medical societies, such as the Brazilian Federation of Gynecology and Obstetrics Societies (Febrasgo, in the Portuguese acronym), to clarify for women the safety of using hormonal contraceptive methods. ${ }^{10}$

Generally speaking, the perception of risks among patients, and even physicians, varies depending on how these risks are presented. ${ }^{11}$ Thus, there is a pressing need for physicians, as primary communicators, to analyze the data, translate them,
Address for correspondence Rogério Bonassi Machado, Federação das Associações de Ginecologia e Obstetrícia, São Paulo, SP, Brazil

(e-mail: editorial.

office@febrasgo.org.br).
DOI https://doi.org/ 10.1055/s-0038-1637742. ISSN 0100-7203.
Copyright $\odot 2018$ by Thieme Revinter Publicações Ltda, Rio de Janeiro, Brazil
License terms

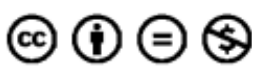


and provide patients with clear, accurate explanations, avoiding controversy and inappropriate conduct. Communicating research results in terms of absolute risk seems to be the most balanced approach.

\section{References}

1 United Nations. Department of Economic and Social Affairs. Population Division. World contraceptive patterns 2013. New York, NY: United Nations; 2013http://www.un.org/en/development/desa/population/publications/pdf/family/worldContraceptivePatternsWallChart2013.pdf Accessed: November 10, 2016

2 Ministério da Saúde. Centro Brasileiro de Análise e Planejamento. Pesquisa Nacional de Demografia e Saúde da Criança e da Mulher: PNDS 2006: dimensões do processo reprodutivo e da saúde da criança. Brasília, DF: Ministério da Saúde; 2009. www.saude. gov.br/pnds2009

3 Pasqualini JR. Progestins and breast cancer. Gynecol Endocrinol 2007;23:32-41

4 Ross JA, Severson RK, Davis S, Stanford JL, Potter JD. Seasonal trends in the self detection of breast cancer: indications from the Cancer Steroid Hormone (CASH) study. Breast Cancer Res Treat 1997;42:187-192
5 Marchbanks PA, McDonald JA, Wilson HG, et al. Oral contraceptives and the risk of breast cancer. N Engl J Med 2002;346:2025-2032

6 Lech MM, Ostrowska L. Risk of cancer development in relation to oral contraception. Eur J Contracept Reprod Health Care 2006; 11:162-168

7 Figueiredo JC, Bernstein L, Capanu M, et al. Oral contraceptives, postmenopausal hormone and risk of asynchronous bilateral breast cancer: the WECARE Study Group. J Clin Oncol 2008;26:1411-1418

8 Hannaford PC, Iversen L, Macfarlane TV, Elliott AM, Angus V, Lee AJ. Mortality among contraceptive pill users: cohort evidence from Royal College of General Practitioners' Oral Contraception Study. BMJ 2010;340:c927

9 Mørch LS, Skovlund CW, Hannaford PC, Iversen L, Fielding S, Lidegaard Ø. Contemporary hormonal contraception and the risk of breast cancer. N Engl J Med 2017;377:2228-2239

10 Federação Brasileira das Associações de Ginecologia e Obstetrícia. Posição da Febrasgo sobre anticoncepcionais hormonais e risco de câncer de mama. 2017. https//febrasgo.org.br/noticias/item/287posicao-da-febrasgo-sobre-anticoncepcionais-hormonais-erisco-de-cancer-de-mama. Acessado Janeiro 5, 2018

11 Machado RB, Santana N, Arruda LF, Reggi N, Gandolpho AC, Siani de Moraes S. How can information on the risk of breast cancer and hormone therapy be better understood? Climacteric 2015; $18: 545-550$ 